\title{
The Hybrid of Jaro-Winkler and Rabin-Karp Algorithm in Detecting Indonesian Text Similarity
}

\author{
Muhamad Arief Yulianto ${ }^{1}$, Nurhasanah ${ }^{2}$ \\ ${ }^{1,2}$ Teknik Informatika, Universitas Pamulang, Indonesia \\ 1dosen02547@unpam.ac.id, ${ }^{2}$ dosen1123@unpam.ac.id
}

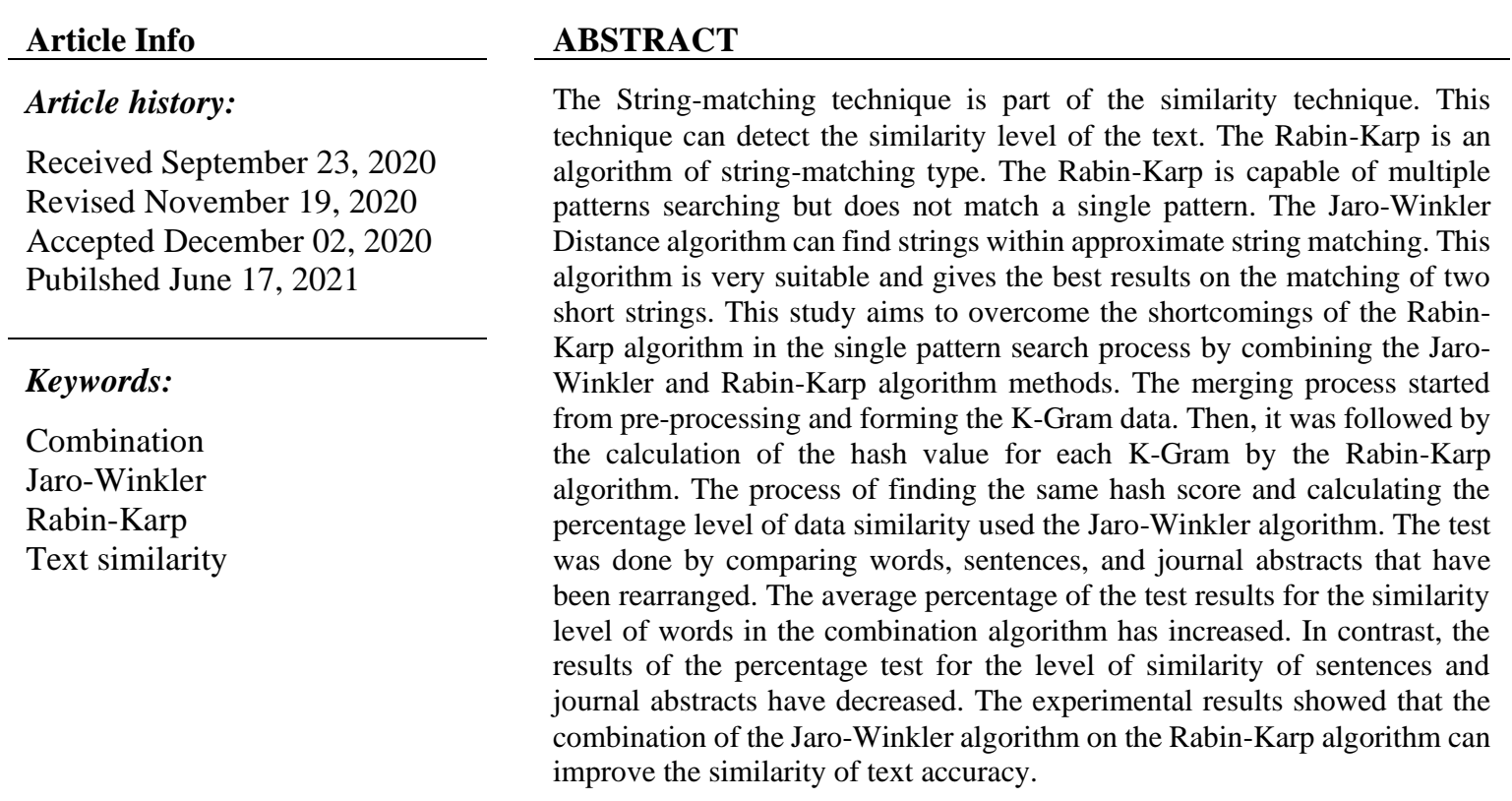

\section{Corresponding Author:}

Muhamad Arief Yulianto, Department of Information Engineering, Universitas Pamulang,

Puspitek Buaran Road, South Tangerang Township 15310, Banten, Indonesia.

Email: dosen02547@unpam.ac.id

\section{INTRODUCTION}

A similarity technique is a widely used fundamental concept. For example, the similarity between the two subjects (A and B) is related to the similarity/difference between them[1]. There are several kinds of algorithms that use string-matching techniques to identify the level text similarity[2]. The algorithm of Rabin-Karp is an algorithm of string-matching type that is useful in several pattern searches[3]. This algorithm uses a hash function to determine the feature value of each word chunk[4]. This algorithm is very suitable to be used to find many patterns in strings[5]. However, this algorithm was not compatible with the process of searching for a single pattern[6]. The application of the algorithm Rabin-Karp has been done by previous research such as detecting documents' plagiarism by Hartanto, et al, 2019[7], Filcha, et al., 2019[8], Steveson, et al., 2018[9], Priambodo, J, 2018[10], Uji Cahyono, Drajad, 2018[11].

In 2017, Andyasah, et al.[12] analyzed the influence of the length of K-Grams in the Rabin-Karp algorithm determining the plagiarism level. The analysis concluded that the determination of the length of the K-Grams affected the percentage level of plagiarism. A higher K-Grams tended to present a lower degree of similarity. Besides, lower K-Grams was able to increase the percentage level of similarity.

Approximate string matching is used in searching string based on the string with the similarity of the writing on the dictionary. The algorithm can be used to search a string including Jaro-Winkler, Hamming, Damerau Levenshtein, and Levenshtein Distance[13]. The Jaro-Winkler algorithm is very suitable and gives the best results on matching two short strings[14]. The using of Jaro-Winkler algorithm has been done by 
previous researchers, namely, the autocorrect and the spelling suggestion[15], [16] feature, detecting plagiarism document[17]-[26], stemming the word compensated is not standard English by Qulub, et al, 2020[27].

In 2016, Rochmawati, et al.[13] conducted research that compared the algorithm of the search string in the approximate string matching methods to identify errors typing text. The methods compared were the Jaro-Winkler, Levenshtein, Hamming, and Damerau Levenshtein Distance. Based on the testing results, it indicated that the algorithm of Jaro-Winkler is the best in checking the word with the value of the MAP is 0.87. The combination of the string-matching and the approximate string-matching algorithms has ever been done by Saberi, et al., 2018[6]. In the research, researchers combined the Levenshtein distance with the algorithm of Rabin-Karp to improve the accuracy of the degree of similarity of the document. The research concluded that the use of the Levenshtein algorithm to calculate the distance of the hash on these two documents will produce a better level of accuracy.

Based on the previous research, it was stated that the Rabin-Karp algorithm was less suitable in the process of finding a single pattern. Besides, the Jaro-Winkler algorithm is very suitable to be applied in the short string searching process. Thus, the researchers intended to combine these two algorithms to deal with the shortcomings of the Rabin-Karp algorithm. The stages start from preprocessing the data, followed by calculating the hash value of each piece of string by the algorithm of Rabin-Karp, then concluding with the calculation of the percentage of the similarity degree of the data using the Jaro-Winkler algorithm. The incorporation of those algorithms is expected to increase the accuracy of the percentage of the similarity degree in text.

\section{METHOD}

The stages of the research implementation can be seen based on the image flowchart below:

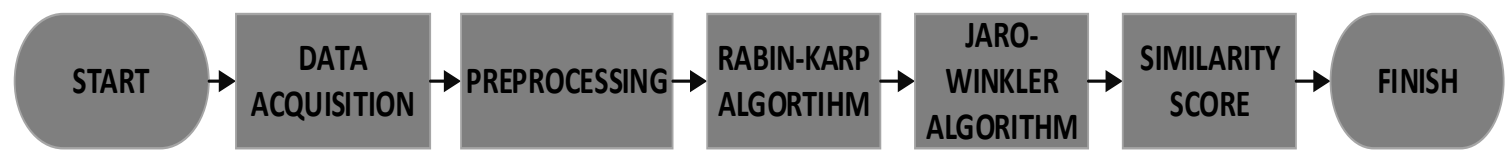

Figure 1. The Hybrid of Jaro-Winkler and Rabin Karp Flowchart

\subsection{Data Acquisition}

The data research used in this research was the abstract data of the study. This data was obtained from various journals or seminars that serve as research source references. The data was converted in the form of text.

\subsection{PREPROCESSING}

The Flowchart below represents the stages of the preprocessing process:

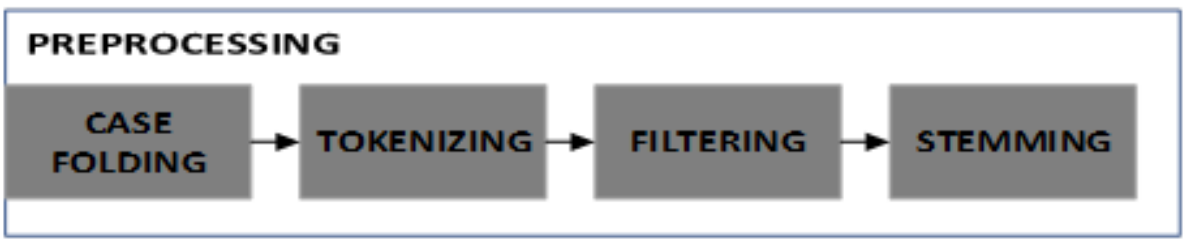

\subsubsection{Case Folding}

Figure 2. Preprocessing

The procedure of changing all letters in the text is all in lowercase[28]. The example (provided in Bahasa Indonesia) of the process of case-folding is in below:

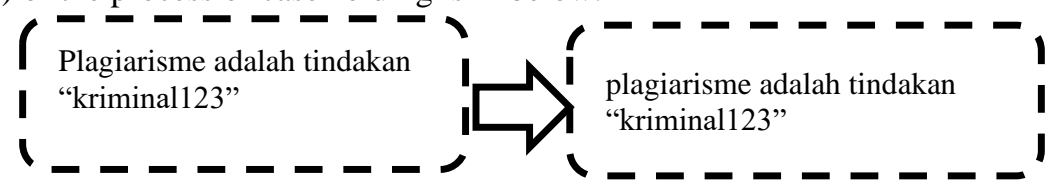

\subsubsection{Tokenizing}

Figure 3. Case Folding

The cutting process of the string is based on each of its constituent words as well as removing the delimiter character[29]. The example of the process of tokenizing is in below: 


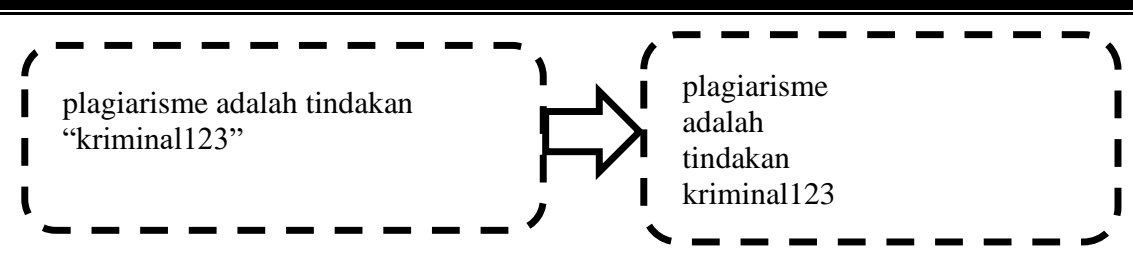

Figure 4. Tokenizing

\subsubsection{Filtering}

The procedure of selecting the important word by eliminating insignificant word, such as conjunction and pronoun [30]. Below is the process of filtering:

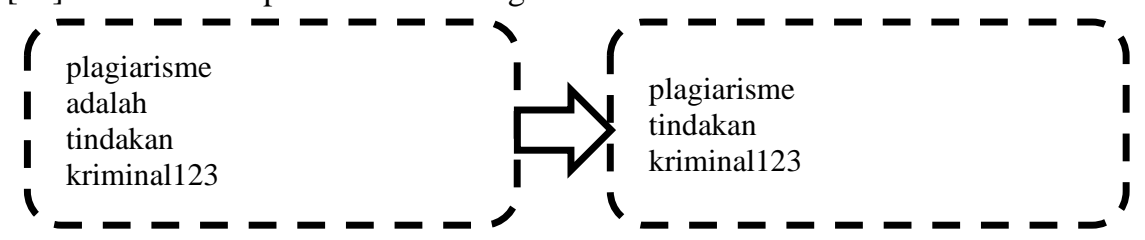

\subsubsection{Stemming}

Figure 5. Filtering

The procedure of discovering the basic word which is used in establishing the feature of the text [31]. The researcher used Nazief\&Adriani algorithm in the stemming process. Below is the process of stemming:

\subsection{Rabin-Karp Algorithm}

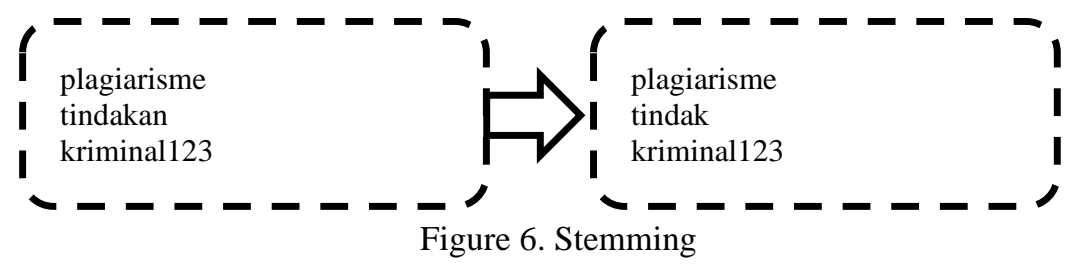

The Algorithm of Rabin-Karp steps can be seen in the flowchart below:

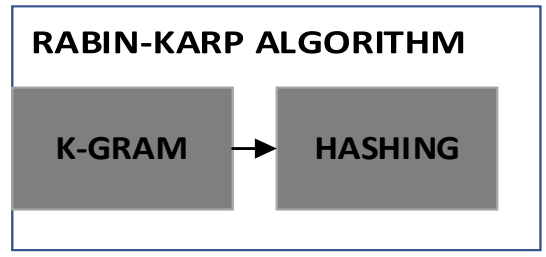

Figure 7. Rabin-Karp Algorithm Process

\subsubsection{K-Gram}

$\mathrm{K}-\mathrm{Gram}$ is the process of forming the word pattern by continuously dividing the word as much as possible from the beginning to the end of the text [32]. Below is the example of the using of k-gram with $\mathrm{k}=3$ value in the text "plagiarismetindakankriminal123":

[pla, lag, agi, gia, iar, ari, ris, ism, sme, met, eti, tin, ind, nda, dak, aka, kan, ank, nkr, kri, rim, imi, min, ina, nal]

\subsubsection{Hashing}

The process to change a string/text into a special value with a permanent length as the string feature. The function which produced the unique value is called as hash function and its result is labeled as value of hash. The similar function of hash is as follow [7]:

$h(s)=\left(s[i] * b^{(n-1)}+s[i+1] * b^{(n-2)}+\cdots+s[i+n-1]\right) \bmod q$

Where :

$h(s)=$ hash value (substring)

$s \quad=$ ASCII value each character

$b=$ Prime Base Numbers

$q \quad=$ modulo

Below is the example of hash calculation from the result of the previous k-gram with parameter value $b=397$ and $\mathrm{q}=1007$ :

$[177,797,515,375,264,854,38,356,115,901,695,60,376,1002,693,81,287,275,777,989,32,991,469$, $373,829]$

The Hybrid of Jaro-Winkler and Rabin-Karp Algorithm in Detecting Indonesian Text Similarity 


\subsection{Jaro-Winkler Algorithm}

The step of Jaro-Winkler Algorithm process can be seen in the flowchart below:

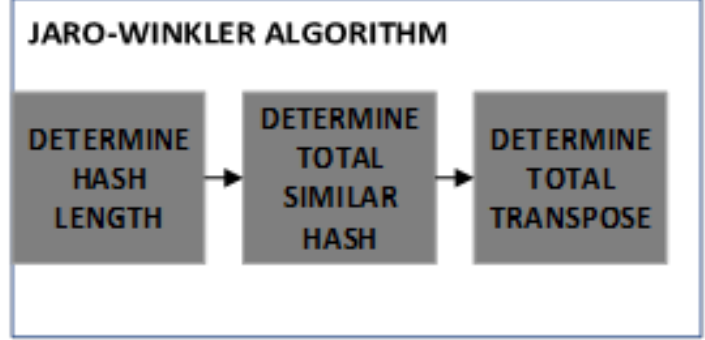

Figure 8. Jaro-Winkler Algorithm Process

\subsubsection{Determine Hash Length}

The program code which used to calculate the number of hash value at text is as follow: nameList.size();

\subsubsection{Determine The Number of Equal Hashes}

The program code which used to establish the number of hash similar:

for (int $x=0 ; i<$ length $1 ; x++$ ) $\left.\mathrm{y}^{++}\right)\{$

for (int $y=$ Math $\max (0, x-$ maxDist) $y<$ Math.min(length2, $x+$ maxDist +1$)$;

\subsubsection{Determine The Number of Transpositions}

The program code that is used to determine the transposition total is as follows:

for (int $\mathrm{x}=0 ; i<$ length $1 ; \mathrm{x}++)\}$ if (hashl[x] $==1) \quad\{$

while (hash2[tip] $==0)$

int listoneTemp $=$ listone.get $(x)$

int listTwoTemp = listTwo.get (tip++);

if (listoneTemp != listTwoTemp )

t++;

\subsection{Similarity Score}

The percentage level calculation of the text similarity in this research used Jaro-Winkler similarity. The determination of similarity text level also used Jaro-Winkler similarity based on Jaro-Winkler similarity is as follows [33]:

$\operatorname{Jaro}_{\left(s_{1}, s_{2}\right)}=\left\{\begin{array}{r}\frac{1}{3} \cdot\left(\frac{m}{\left|s_{1}\right|}+\frac{m}{\left|s_{2}\right|}+\frac{m-t}{m}\right): m>0 \\ 0 \quad \text { otherwise }\end{array}\right.$

Where :

$$
\begin{array}{ll}
\left|s_{1}\right|,\left|s_{2}\right| & =\text { both strings length(hash) } \\
m & =\text { matching characters number(hash) } \\
t & =\text { transpositions number }
\end{array}
$$

The program code used in the calculation process of Jaro similarity is as follows public double jaro_distance(ArrayList<Integer $>$ arrList1, ArrayList $<$ Integer $>$ arrList2) \{

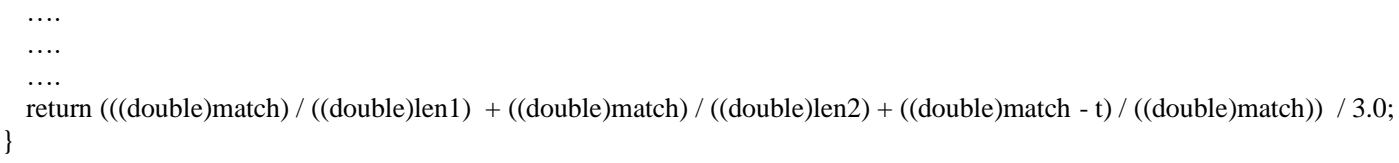


The Jaro-Winkler similarity equation was obtained by adding the same prefix in the Jaro similarity value as follows:

$\operatorname{JaroWinkler}_{\left(s_{1}, s_{2}\right)}= \begin{cases}\operatorname{Jaro}_{\left(s_{1}, s_{2}\right)}+l \cdot p \cdot\left(1-\operatorname{Jaro}_{\left(s_{1}, s_{2}\right)}\right) & : \operatorname{Jaro}_{\left(s_{1}, s_{2}\right)} \geq b_{t} \\ \operatorname{Jaro}_{\left(s_{1}, s_{2}\right)} & : \text { otherwise }\end{cases}$

Where :

$$
\begin{array}{ll}
\operatorname{Jaro}_{\left(s_{1}, s_{2}\right)} & =\text { Jaro Distane Value } \\
l & =\text { common prefix up to maks } 4 \\
p & =\text { prefix scale constant }(p=0.1) \\
b_{t} & =\text { boost treshold }\left(b_{t}=0.7\right)
\end{array}
$$

The program code used in the calculation process of Jaro-Winkler similarity is as follows: public double jaro_winkler(ArrayList $<$ Integer $>$ arrList1, ArrayList $<$ Integer $>$ arrList2, double jaro_distance) \{

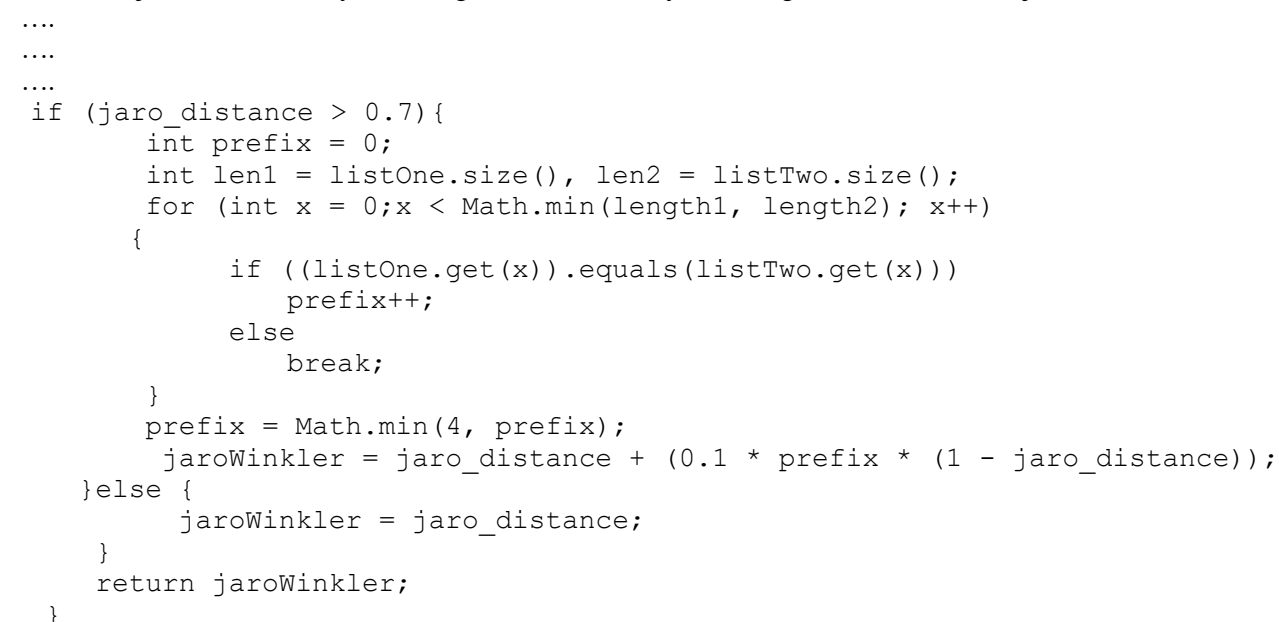

\section{RESULTS AND DISCUSSION}

In this research, the researcher executed a process using three types of data input in the form of word, sentence and abstract of journal in Indonesian language. In the process of testing level of data similarity, a process of changing letter, word, and sentence arrangement was carried out againts the data that have been made. Meanwhile, journal abstracts were also tested on several journals with the same theme. The word similarity test data was obtained from the original data which changes the position of the letters by k-grams, while the sentence and journal similarity test data is obtained from the results of changes in the structure of words or sentences as much as n-grams. The values for the K-Gram, Basis and Modulo parameters for RabinKarp used in this study were 3, 397 and 1007 respectively. The merging process of algorithms started from pre-processing and forming the K-Gram data. Then, it was followed by the calculation of the hash value for each K-Gram by the Rabin-Karp algorithm. The process of finding the same hash score and calculating the percentage level of data similarity used the Jaro-Winkler algorithm. The result of tests are shown below:

\subsection{Word Similarity Test Results}

In the process of testing the level of similarity words have done by comparing between the same words, but the letter arrangement is changed. Meanwhile, the number of letters whose positions were exchanged in the testing process for each word is one alphabet, two alphabets, and three alphabets with the position of being replaced randomly. The data and test results are as follows:

\begin{tabular}{cll}
\multicolumn{2}{c}{ Table 1. Word Similarity Test Data } \\
\hline Base Word & \multicolumn{1}{c}{ Testing Word } & $\begin{array}{c}\text { Number of Alphabets } \\
\text { Swapping }\end{array}$ \\
\hline Plagiarism & $\begin{array}{c}\text { palgiarisme } \\
\text { palgairisme }\end{array}$ & $\begin{array}{l}\text { One Alphabet } \\
\text { Two Alphabets }\end{array}$ \\
& palgairisem & Three Alphabets \\
Konsultasi & konslutasi & One Alphabet \\
& konslutsai & Two Alphabets \\
& konslutsia & Three Alphabets \\
Dokumentasi & dokumentsai & One Alphabet \\
& dkoumentsai & Two Alphabets \\
& dkoumnetsai & Three Alphabets \\
Keterlambatan & keterlmabatan & One Alphabet \\
& kteerlmabatan & Two Alphabets \\
& kteerlmabtaan & Three Alphabets \\
Berorientasi & berorientsai & One Alphabet \\
& breorientsai & Two Alphabets \\
& breorientsia & Three Alphabets \\
\hline
\end{tabular}

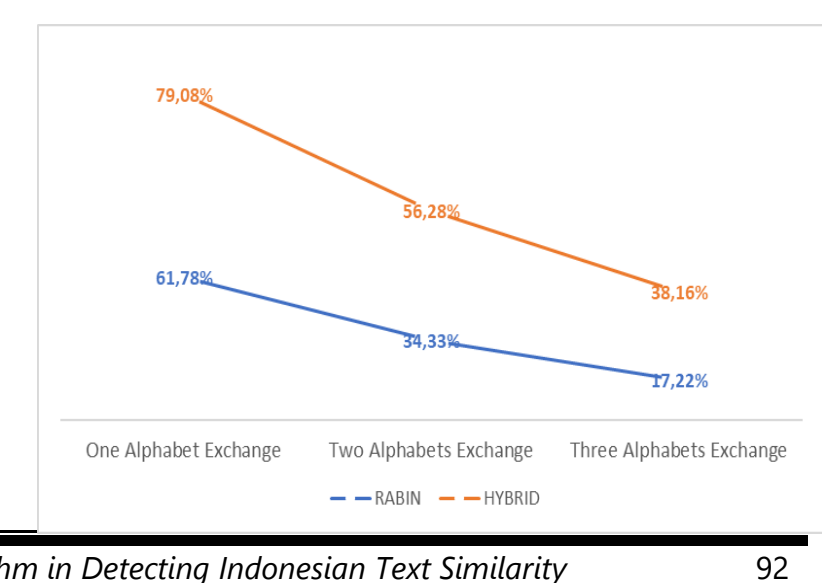

(IVIunamaa Arlet Yulıanto', IVurnasanan IVurnasanah'²) 
Figure 9. Word Similarity Test Results

The line chart above was obtained based on the testing between two similar words but changing the letter position. The changes of letter position were executed in three different variants, namely a change in the position of 1 letter, 2 letters, and 3 letters. The diagram results above shows that the combination algorithm have a higher accuration level than Rabin-Karp algorithm.

\subsection{Sentence Similarity Test Results}

In line with the process of testing the level of word similarity, testing the level of sentences similarity were also carried out by changing the word order in the same sentence. The number of words whose positions were exchanged in the testing process for each sentence is one word, two, three, and four words with the position of being replaced randomly. The data and test results are as follows:

Table 2. Sentence Similarity Test Data

\begin{tabular}{|c|c|c|}
\hline Base Sentence & Testing Sentence & $\begin{array}{l}\text { Number of Word } \\
\text { Swapping }\end{array}$ \\
\hline \multirow[t]{4}{*}{$\begin{array}{l}\text { anton menendang kuda } \\
\text { di lapangan. }\end{array}$} & $\begin{array}{l}\text { menendang anton kuda di } \\
\text { lapangan }\end{array}$ & One Word \\
\hline & $\begin{array}{l}\text { menendang kuda anton di } \\
\text { lapangan }\end{array}$ & Two Words \\
\hline & $\begin{array}{l}\text { menendang di lapangan } \\
\text { kudda anton }\end{array}$ & Three Words \\
\hline & $\begin{array}{l}\text { di lapangan menendang } \\
\text { kuda anton }\end{array}$ & Four Words \\
\hline \multirow[t]{4}{*}{$\begin{array}{l}\text { Budi memakan Daging } \\
\text { Kemarin }\end{array}$} & $\begin{array}{l}\text { Memakan Budi Daging } \\
\text { Kemarin }\end{array}$ & One Word \\
\hline & $\begin{array}{l}\text { Memakan Daging Budi } \\
\text { Kemarin }\end{array}$ & Two Words \\
\hline & $\begin{array}{l}\text { Daging Memakan Budi } \\
\text { Kemarin }\end{array}$ & Three Words \\
\hline & $\begin{array}{l}\text { Kemarin Daging Memakan } \\
\text { Budi }\end{array}$ & Four Words \\
\hline \multirow{4}{*}{$\begin{array}{l}\text { Ayah Menulis Surat } \\
\text { Undangan } \\
\text { Kemarin }\end{array}$} & Kemarin Ayah Menulis & One Word \\
\hline & $\begin{array}{l}\text { Kemarin Ayah Menulis } \\
\text { Undangan Surat Sunat }\end{array}$ & Two Words \\
\hline & $\begin{array}{l}\text { Kemarin Ayah Menulis } \\
\text { Undangan Sunat Surat }\end{array}$ & Three Words \\
\hline & $\begin{array}{l}\text { Kemarin Menulis Avah } \\
\text { Undangan Sunat Surat }\end{array}$ & Four Words \\
\hline
\end{tabular}

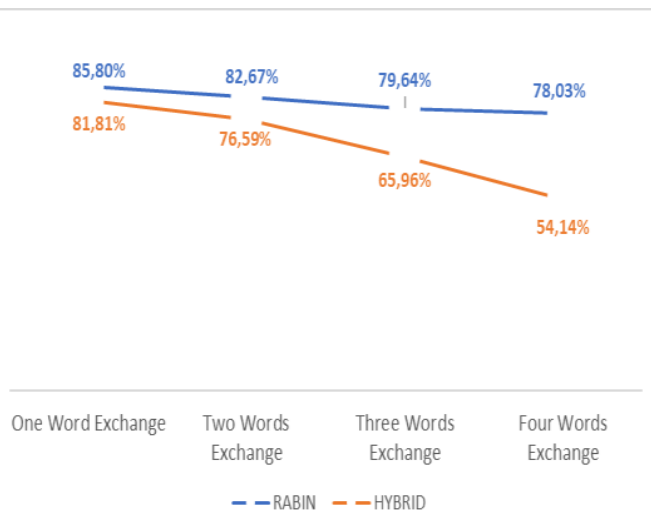

Figure 10. Sentence Similarity Test Results

The line chart above was obtained based on testing between the same two sentences but by changing the word position. Changes in word position were carried out in four different variants, namely changing the placement of one word, two, three and four words. Based on these results, it indicated that the combination algorithm possessed a lower level of accuracy than the Rabin-Karp algorithm.

\subsection{Journal Abstract Similarity Test Results}

The process of testing the similarity of Indonesian language journal abstract was not only done by testing the same journal by changing the order of words and sentences, but also testing it with journal abstracts that have the same theme. The data and test results are as follows:

Table 3. Journal Abstract Similarity Test Result

\begin{tabular}{lll}
\hline Abstract Journal Testing & $\begin{array}{l}\text { Rabin-Karp } \\
\text { Similarity }\end{array}$ & $\begin{array}{l}\text { Hybrid Algorithm } \\
\text { Similarity }\end{array}$ \\
\hline Three Word Exchange & $99.17 \%$ & $93.42 \%$ \\
Six Word Exchange & $98.34 \%$ & $91.52 \%$ \\
\hline Nine Word Exchange & $98.06 \%$ & $89.91 \%$ \\
\hline Twelve Word Exchange & $97.23 \%$ & $89.29 \%$ \\
\hline Fifteen Word Exchange & $96.67 \%$ & $88.32 \%$ \\
One Sentence Exchange & $99.72 \%$ & $93.50 \%$ \\
\hline Two Sentence Exchange & $99.58 \%$ & $87.47 \%$ \\
\hline Three Sentence Exchange & $99.45 \%$ & $82.41 \%$ \\
\hline Similar Topics & $78.88 \%$ & $49.63 \%$ \\
Similar Topics & $87.55 \%$ & $52.28 \%$ \\
\hline Similar Topics & $93.86 \%$ & $49.62 \%$ \\
\hline
\end{tabular}
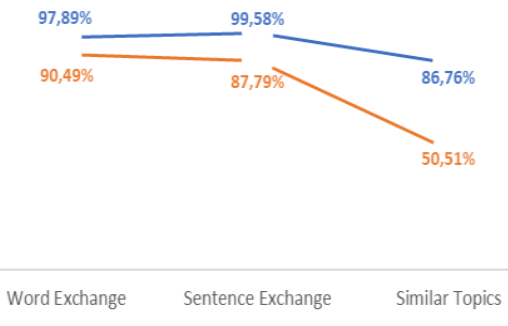

-- RABIN -- HYBRID

Figure 11. The Average Journal Abstract Similarity Test Results 
The line chart above was obtained based on testing between the same two journal abstracts by changing the position of words and sentences. Changes in word position were carried out in five different variants, namely changing the placement of three words, six words, nine words, 12 words and 15 words. Meanwhile, changes in sentence position were carried out in three different variants, namely changing the placement of one sentence, two sentences and three sentences. The sentence and abstract similarity test data was formed based on changes in word and sentence structure as much as n-grams. This was done, because if you made changes to the arrangement of k-grams, the resulting test data will not change much from the original data. Moreover, the researcher also conducted the testing of journals which considered the same theme.

\section{CONCLUSION}

The test results above showed that it improved the presentation of the accuracy of the Rabin-Karp algorithm on the word similarity test by $20.06 \%$ through the implementation of the Jaro-Winkler algorithm on Rabin-Karp. However, the percentage level in testing the similarity of sentences and journal abstracts decreased by $15.20 \%$. It showed that the implementation of the Jaro-Winkler algorithm on Rabin-Karp could improve the accuracy in detecting text similarities. Future research is expected to be able to analyze the implementation time in determining the level of text similarity using a web-based application.

\section{ACKNOWLEDGEMENTS}

The researcher would like to thank the Ministry of Research and Technology/National Agency for Research and Innovation for providing research grants. Dr. (HC) H. Darsono as Chairman of the Sasmita Jaya Foundation, Pamulang University. Dr. Ali Madinsyah and the LPPM team from Pamulang University who facilitated and provided guidance during the research implementation.

\section{REFERENCES}

[1] H. Ezzikouri, M. Erritali, and M. Oukessou, "Semantic Similarity / Relatedness for Cross Language Plagiarism Detection," vol. 1, no. 2, pp. 371-374, 2016, doi: 10.11591/ijeecs.v1.i2.pp371-374.

[2] B. Leonardo and S. Hansun, "Text documents plagiarism detection using Rabin-Karp and Jaro-Winkler distance algorithms," Indones. J. Electr. Eng. Comput. Sci., vol. 5, no. 2, pp. 462-471, 2017, doi: 10.11591/ijeecs.v5.i2.pp462471.

[3] D. Leman, M. Rahman, F. Ikorasaki, B. S. Riza, and M. B. Akbbar, "Rabin Karp and Winnowing Algorithm for Statistics of Text Document Plagiarism Detection," 2019 7th Int. Conf. Cyber IT Serv. Manag. CITSM 2019, 2019, doi: 10.1109/CITSM47753.2019.8965422.

[4] A. P. U. Siahaan, "Rabin-Karp Elaboration in Comparing Pattern Based on Hash Data," Int. J. Secur. Its Appl., vol. 12, no. 2, pp. 59-66, 2018, doi: 10.14257/ijsia.2018.12.2.06.

[5] A. Bahrul Khoir, H. Qodim, B. Busro, and A. Rialdy Atmadja, "Implementation of rabin-karp algorithm to determine the similarity of synoptic gospels," J. Phys. Conf. Ser., vol. 1175, no. 1, 2019, doi: 10.1088/17426596/1175/1/012120.

[6] A. P. U. Siahaan et al., "Combination of levenshtein distance and rabin-karp to improve the accuracy of document equivalence level," Int. J. Eng. Technol., vol. 7, no. 2 Special Issue 27, pp. 17-21, 2018, doi: 10.14419/ijet.v7i2.27.12084.

[7] A. D. Hartanto, A. Syaputra, and Y. Pristyanto, "Best parameter selection of rabin-Karp algorithm in detecting document similarity," 2019 Int. Conf. Inf. Commun. Technol. ICOIACT 2019, no. February 2020, pp. 457-461, 2019, doi: 10.1109/ICOIACT46704.2019.8938458.

[8] A. Filcha and M. Hayaty, "Implementasi Algoritma Rabin-Karp untuk Pendeteksi Plagiarisme pada Dokumen Tugas Mahasiswa," JUITA J. Inform., vol. 7, no. 1, p. 25, 2019, doi: 10.30595/juita.v7i1.4063.

[9] D. Steveson, H. Agung, and F. Mulia, "APLIKASI PENDETEKSI PLAGIARISME TUGAS DAN MAKALAH PADA SEKOLAH MENGGUNAKAN ALGORITMA RABIN," J. Algoritm. Log. dan Komputasi, vol. 1, no. 1, pp. 12-17, 2018, [Online]. Available: https://journal.ubm.ac.id/index.php/alu.

[10] J. Priambodo, "Pendeteksian Plagiarisme Menggunakan Algoritma Rabin-Karp dengan Metode Rolling Hash," $J$. Inform. Univ. Pamulang, vol. 3, no. 1, p. 39, 2018, doi: 10.32493/informatika.v3i1.1518.

[11] D. Uji Cahyono, "Aplikasi Deteksi Dini Plagiarisme Judul Tugas Akhir Mahasiswa Sekolah Tinggi Ilmu Kesehatan Yayasan Rs. Islam Surabaya Dengan Algoritma Rabin-Karp,” Appl. Technol. Comput. Sci. J., vol. 1, no. 1, pp. 1-10, 2018, doi: 10.33086/atcsj.v1i1.3.

[12] A. P. U. Siahaan, R. Rahim, M. Mesran, and D. Siregar, "K-Gram As A Determinant Of Plagiarism Level in RabinKarp Algorithm," Int. J. Sci. Technol. Res., vol. 06, no. 07, pp. 350-353, 2017, doi: 10.31219/osf.io/yxjnp.

[13] Y. Rochmawati and R. Kusumaningrum, "Studi Perbandingan Algoritma Pencarian String dalam Metode Approximate String Matching untuk Identifikasi Kesalahan Pengetikan Teks," J. Buana Inform., vol. 7, no. 2, pp. 125-134, 2016, doi: 10.24002/jbi.v7i2.491.

[14] D. Z. Putri, D. Puspitaningrum, and Y. Setiawan, "Konversi Citra Kartu Nama ke Teks Menggunakan Teknik OCR dan Jaro-Winkler Distance," J. Teknoinfo, vol. 12, no. 1, p. 1, 2018, doi: 10.33365/jti.v12i1.35.

[15] K. M. Suryaningrum and A. T, "Pengkoreksian dan Suggestion Word pada Keyword Menggunakan Algoritma JaroWinkler,” J. Teknol. Informasi-AITI, vol. 13, no. 2, pp. 169-181, 2016. 
[16] A. Prasetyo, W. M. Baihaqi, and I. S. Had, "Algoritma Jaro-Winkler Distance: Fitur Autocorrect dan Spelling Suggestion pada Penulisan Naskah Bahasa Indonesia di BMS TV," J. Teknol. Inf. dan Ilmu Komput., vol. 5, no. 4, p. 435, 2018, doi: 10.25126/jtiik.201854780.

[17] S. C. Cahyono, "Comparison of document similarity measurements in scientific writing using Jaro-Winkler Distance method and Paragraph Vector method," IOP Conf. Ser. Mater. Sci. Eng., vol. 662, no. 5, 2019, doi: 10.1088/1757$899 X / 662 / 5 / 052016$.

[18] P. Novantara, "Implementasi Algoritma Jaro-Winkler Distance Untuk Sistem Pendeteksi Plagiarisme Pada Dokumen Skripsi,” Buffer Inform., vol. 3, no. 1, 2018, doi: 10.25134/buffer.v3i2.960.

[19] S. Christina, E. D. Oktaviyani, and B. Famungkas, "Mendeteksi Plagiarism Pada Dokumen Proposal Skripsi Menggunakan Algoritma Jaro Winkler Distance," J. SAINTEKOM, vol. 8, no. 2, p. 143, 2018, doi: 10.33020/saintekom.v8i2.68.

[20] I. E. Agbehadji, H. Yang, S. Fong, and R. Millham, "The Comparative Analysis of Smith-Waterman Algorithm with Jaro-Winkler Algorithm for the Detection of Duplicate Health Related Records," 2018 Int. Conf. Adv. Big Data, Comput. Data Commun. Syst. icABCD 2018, 2018, doi: 10.1109/ICABCD.2018.8465458.

[21] T. Tinaliah and T. Elizabeth, "Perbandingan Hasil Deteksi Plagiarisme Dokumen dengan Metode Jaro-Winkler Distance dan Metode Latent Semantic Analysis," J. Teknol. dan Sist. Komput., vol. 6, no. 1, pp. 7-12, 2018, doi: 10.14710/jtsiskom.6.1.2018.7-12.

[22] Jayanta, H. Mahfud, and T. Pramiyati, "Analisis pengukuran self plagiarism menggunakan algoritma Rabin-Karp dan Jaro-Winkler distance dengan stemming Tala," Semin. Nas. Teknol. Inf. dan Multimed., vol. 5, no. 1, pp. 1-6, 2017.

[23] M. J. Tannga, S. Rahman, and Hasniati, "Analisis Perbandingan Algoritma Levenshtein Distance Dan Jaro Winkler Untuk Aplikasi Deteksi Plagiarisme Dokumen Teks," Jtriste, vol. 4, no. 1, pp. 44-54, 2017.

[24] L. Hakim, "Penggunaan N-Gram dan Jaro Winkler Distance pada Aplikasi Kelas Daring untuk Deteksi Plagiat," in Seminar Nasional Sains dan Teknologi 2019, 2019, pp. 1-10, [Online]. Available: jurnal.umj.ac.id/index.php/semnastek.

[25] S. Sugiono, H. Herwin, H. Hamdani, and E. Erlin, "Aplikasi Pendeteksi Tingkat Kesamaan Dokumen Teks: Algoritma Rabin Karp Vs. Winnowing," Digit. Zo. J. Teknol. Inf. dan Komun., vol. 9, no. 1, pp. 82-93, 2018, doi: 10.31849/digitalzone.v9i1.1242.

[26] S. C. Cahyono, "Comparison of document similarity measurements in scientific writing using Jaro-Winkler Distance method and Paragraph Vector method," IOP Conf. Ser. Mater. Sci. Eng., vol. 662, p. 52016, 2019, doi: 10.1088/1757$899 x / 662 / 5 / 052016$.

[27] M. Qulub, E. Utami, and A. Sunyoto, "Stemming Kata Berimbuhan Tidak Baku Bahasa Indonesia Menggunakan Algoritma Jaro-Winkler Distance," Creat. Inf. Technol. J., vol. 5, no. 4, p. 254, 2020, doi: 10.24076/citec.2018v5i4.218.

[28] A. F. Hidayatullah, "The influence of stemming on Indonesian tweet sentiment analysis," Int. Conf. Electr. Eng. Comput. Sci. Informatics, vol. 2, no. August, pp. 127-132, 2015, doi: 10.11591/eecsi.v2i1.791.

[29] D. A. Putra and H. Sujaini, "Implementasi Algoritma Rabin-Karp untuk Membantu Pendeteksian Plagiat pada Karya Ilmiah(CONTOH PLAGIAT)," J. Sist. dan Teknol. Inf., vol. 4, no. 1, pp. 66-74, 2015, [Online]. Available: http://jurnal.untan.ac.id/index.php/justin/article/view/12411.

[30] M. V Bhosale and A. A. Vankudre, "Detection of Real-Time Traffic through Twitter Stream Analysis," J. Adv. Eng. Sci., vol. 2, no. 2, pp. 124-126, 2017.

[31] P. M. Prihatini, I. K. G. D. Putra, I. A. D. Giriantari, and M. Sudarma, "Stemming Algorithm for Indonesian Digital News Text Processing," Int. J. Eng. Emerg. Technol., vol. 2, no. 2, pp. 1-7, 2017.

[32] P. Internal, M. Algoritma, and T. Informatika, "SATIN - Sains dan Teknologi Informasi Sistem Pendeteksi Tingkat Kesamaan Teks pada Pengusulan Proposal,” SATIN - Sains dan Teknol. Inf., vol. 4, no. 2, pp. 84-91, 2018. 